\title{
Strategic Management Applications in Rejuvenation Efforts of South-Western Nigerian Hotels: Facilities Management Perspective
}

\author{
Olufemi Daniel Durodola (Corresponding author) \\ Department of Estate Management, School of Environmental Sciences \\ College of Science and Technology, Covenant University \\ Ota, Ogun State, Nigeria \\ E-mail: daniel.durodola@yahoo.com
}

Caleb Abiodun Ayedun

Department of Estate Management, School of Environmental Sciences

College of Science and Technology, Covenant University

Ota, Ogun State, Nigeria

E-mail: caayedun@yahoo.com

Ayotunde Olawande Oni

Department of Estate Management, School of Environmental Sciences

College of Science and Technology, Covenant University

Ota, Ogun State, Nigeria

E-mail:wandeoni@yahoo.com

Received: November 5, $2011 \quad$ Accepted: December 7, $2011 \quad$ Published: March 1, 2012

doi:10.5539/jms.v2n1p29 URL: http://dx.doi.org/10.5539/jms.v2n1p29

\begin{abstract}
A survey was conducted of probabilistically determined fifty-seven hotels of various 'stars' in South-Western geo-political zone of Nigeria to investigate the responsiveness of the hotel organizations to strategic property management practices in particular level of use of facilities management, level of commitment to business development, use of information and communication technology and support services procurement methodology. Data were collected from hotel organizations through their general managers, staff and customers with the aid of questionnaires. A combination of stratified and cluster sampling techniques were used. Kothari's formula was adopted to determine the appropriate sample size while descriptive statistics and balanced score card were used for data analysis. It was found that use of facilities management as a strategic management instrument is at low ebb (36\%), the same is true of level of commitment to business development (46\%), use of information and communication technology (39\%) and support services outsourcing (46\%). The use of balanced score card principle shows that the four variables all less than 50\% may be balanced but in a negative sense suggesting non-responsiveness to the use of strategic management practices. This discovery also affirms that receptivity to FM is at low-ebb in the hotel sector of Nigeria's economy and a pointer to ignorance of FM as instrument of strategic change. The study recommended that International Facilities Management Association (Nigeria Group), hotel organizations and Governments at all levels in Nigeria should be conscious of this development and put in place strategic actions to educate the gentries on the efficacy of FM in running hotel businesses. The hotel managements are also encouraged to be responsive to new ways of doing things especially when such a method would have a tremendous impact on the performance of the hotels.
\end{abstract}

Keywords: Facilities management, Hotel, Strategic management, Change management 


\section{Introduction}

In a demand led economy, marketing is a strategic management instrument for sustainable development. Marketing has been defined as "the management process responsible for identifying, anticipating and satisfying customer requirement profitably" (Bevan, 1991). Bevan (1991), explicated the definition further by observing that by "management process", marketing must be planned, implemented and monitored. The twin word "identifying" and "anticipating" mean that marketing requires research and analysis of customers' needs and how such needs could be satisfied. By "satisfaction of needs" the product/service design and production must ensure that the needs are fully met. Since the business of every business is to remain in business, profitability must be the main goal of marketing and this proposition tends to be the main focus of any major on-going concern.

Despite the fact that business organizations imbibe the philosophy of marketing and pursue it aggressively, such entities still crumble for some reasons. This situation has been aided by economic depression, which is now worsened by the world's financial melt-down. Businesses worldwide now realize the vitality of demand and supply of goods and services and in order to safeguard their business interests tend to embark on strategic management, which comes in various forms like financial engineering, mergers and acquisition, privatization and commercialization, complete buy out, sales and lease back, among others believing that such scenarios will create synergies that would turn the business organizations around. Today, strategic management is thought of as a way of managing a company whereby the overall strategy and purposes of the firm dominate decision-making at all levels and in all functions of the company. No longer is it sufficient for the Chief Executive alone to have a sense of where the company is headed. Strategy must be communicated with sufficient clarity so that it can dominate action throughout the organization (Collins and Devanna, 1990).

The economic and social impacts of the current global financial crisis are enormous. It has damaged global markets and economies around the world: the industrialized western economies, the newly industrializing economies of East Asia, Latin American, and the Middle-East and African economies. It has exacerbated political crisis in such countries like Egypt, Tunisia, Syria and Libya among others. It has affected business operations and investments by way of reducing domestic and international demand for goods and services pushing up unemployment as many industries and organizations are shedding off workers. The global economic downturn has also affected national income and budgets, exchange rates and interest rates, and slowed down economic growth in societies around the globe.

The long-term effect might exacerbate Nigeria's social and economic problems. It is the management of constant change that is expected to drive effective companies and organizations in order for them to mellow down the impact of economic downturn on their operation and profitability. Strategic management application must therefore be a continuous process but more importantly when a company has gone through the four stages of the life cycle namely, birth, growth, diversification and decline. At that time, it is necessary to appraise the entire operations of the organization including its operational philosophy, mission and vision statement, structure, design and strategic plans. This exercise is necessary in order to ensure the survival of the organization and to empower it to cope with the challenges ahead. This is however only achievable within a broad framework of well-articulated corporate strategy driven by a strategic management philosophy. Strategic management as a concept therefore entails the analysis of the environment, planning and forecasting, formulation of corporate functional plans, performance measurement and control, resource allocation, management audit and the establishment of benchmarks (Rufai, 2003).

One clear area of effective management, which may be extremely lacking in hotel management in Nigeria is in the area of strategic management which Torkildsen (1992) called "operational excellence" that involves taking strategic decisions. This strategic approach to hotel business development is what is in vogue in advanced countries of the world today along with facilities management, mergers and acquisition, expansion of brands, strengthening of guest loyalty, aggressive maintenance, and new technology and marketing strategy (Telfer, 2005). Thus, effective organizations must put in place marketing strategies, asset management strategies and business development strategies if they are to remain in the market place.

It is imperative to state that facilities management is one of these strategic management concepts that organizations employ to remain afloat and satisfy their innovation strategies (Torkildsen, 1992). According to Green and Price (2000) citing Nutt (1999) and Grimshaw (2003), recent business and academic writings have emphasized that facilities management as a discipline must evolve to higher strategic level if the business is to extract the best value from it. The beauty of strategic management is the multiplicity of available options to pick from which itself present a vicious problem to change inclined managers. This then necessitates rigorous 
appraisal of available options before final decision is taken. One clear variable is the benefits accruable from whatever strategy that is adopted no matter the sector of the economy that is being considered. If strategic management is viewed as being beneficial and effective, how committed are the hotel organizations to re-engineering?

A major area of the Nigerian economy, which should attract such investigation, is the hotel and hospitality industry. This industry is crucial to the growth and development of tourism as a foreign exchange spinner for many countries of the world, Nigeria inclusive. The most interesting aspect of hotel development is the continued interest, which the private sector is showing in its development. For instance, Ibru Organizations bought over Federal Palace Hotel from the Federal Government and subjected it to refurbishment for greater service. The same organization also owns Ikeja Sheraton Hotel and Towers. Kuku Organizations developed the Grand Hotel, Asaba and is now proposing to develop a larger version in Lagos to be named Ikoyi Grand Hotel. Global Oil Fleet Organizations purchased the extensive Federal Government Guest House at Victoria Island Lagos and proposed to turn it into a 5-star Hotel complex along the ones the organization is already operating at Port Harcourt and Lekki-Ajah axis of Lagos (Dada, 2005). Sunny Side Corporation of U.S.A bought over the former Ikoyi Hotel now re-named Southern Sun hotel from the Federal Government and subject it to extensive renovation to revive its degenerated facilities. The former Durbar Hotel Lagos was bought over by UACN Property Development Company Plc and now re-constructed to a 5-star hotel with modern facilities. Despite the non-proactive nature of facilities maintenance in some of these hotels, other hotels in Nigeria are not left behind in the adoption of facilities management as strategic management principle to get hold of the market going by what are being published in the daily newspapers; for instance Sheraton Hotel and Towers, Ikeja Lagos, Le Meridien Hotel, Victoria Island Lagos and Nicon Hilton Hotel, Abuja (Bode-Thomas, 2003). Hotel organizations are not immune to the influences of the economy and business cycles, so the difficulties that befall business in general during economic down-turns also affect hotel organizations. Downsizing, reengineering, facilities management and strategic estate management are some of the strategic tools being used to describe the changes hotel companies have undergone or are undergoing Rutherford (2002). If these colossal investments are to be retained, sustained and accelerated, there is the need to investigate the responsiveness of these hotel organizations to the adoption of facilities management as an instrument of strategic change. The main objective of the research therefore is to assess the extent of application of facilities management as an instrument of strategic management in the running of hotel organizations in Nigeria. This is achieved by examining the degree of use of facilities management as property management style; level of use of business development instrument and level of compliance with information and communication technology. The paper is structured into five major segments namely introduction, literature review, the research method, result and discussion, conclusion and recommendations.

\section{Literature review}

Spedding (1999) concurred with International Facilities Management Association (IFMA) definition of FM in its early days as: - "the practice of coordinating the physical workplace with the people and work of the organization, integrating the principles of business administration, architecture and behavioral and engineering sciences". This definition focuses on unity in diversity that must necessarily be a concern to organizations. However, the real business area of FM was not highlighted which include space management and support service management among others.

Apart from Spedding (1999) and IFMA's concept of FM, there are other variances of FM definitions. This was corroborated by the Royal Institution of Chartered Surveyors (RICS) Research Report of 1999 which highlighted such definitions. Becker (1999) [In Cowan (2001)] defined facilities management as "being responsible for co-ordinating all efforts relating to planning, designing and managing buildings and their systems, equipment and furniture to enhance the organization's ability to compete in a rapidly changing world". This definition focuses on building and tries to make FM wider than necessary; although it could be compared with RICS definition, which regards it as "the total management of all services that support the core business of an organization".

A more detailed definition is offered by Engineering News-Record of April $4^{\text {th }}, 1985$ (In Hamer, 1988) as "the discipline of planning, designing, constructing and managing space - in every type of structure from office buildings to process plants. It involves developing corporate facilities' policy, long-range forecasts, real estate, space inventories, and projects through design, construction and renovation, building operation and maintenance plans and furniture and equipment inventories". This definition emphasizes space management, which was missing in IFMA's definition but ignored FM as one of the strategic tools that could be used in turning a company around. Jim Steinmann (In Hamer, 1988) opined that Facilities Management is the systematic approach 
to inventorying, planning, designing and maintaining space, equipment and furniture for general or special purpose facilities that are flexible to accommodate change. This definition added space inventory and recognition of FM as an instrument to sustain "change" programme of an organization.

Alexander (1996) defines facilities management as "the process by which an organization ensures that its buildings, systems and services support core operations and processes as well as contribute to achieving its strategic objectives in changing conditions. It focuses on meeting users" needs to support key role of people in organizations and strives to continuously improve quality, reduce risks and ensure value for money. It is clearly an important management function and business service. Major organizations worldwide use it as part of their strategy for restructuring to provide competitive edge. It also ensures that buildings and support services improve customer responsiveness and contribute to business objectives. Alexander (1996) emphasized the fact that facilities management is purely an instrument to support the core business of an organization with the aim of making it more efficient and more productive.

Regterschot (1988) (In Udo, 1998) described facilities management as "the integral management (planning and monitoring) and realization of housing, services and means that must contribute to an effective, flexible and creative realization of an organization's objectives in an ever changing environment". Furthermore it is an instrument for accounting for available space and services with the aim of reducing cost and increasing profit. Hamer (1988) described FM "as the process of planning, implementing, maintaining and accounting for appropriate physical spaces and services for an organization, while simultaneously seeking to reduce the associated total cost". This definition introduced workplace as an instrument of strategic management, and considered it as an instrument for accounting for available space and services with the aim of reducing cost and improving profit. From the total quality point of view, FM is the process by which an organization delivers and sustains support services in a quality environment to meet strategic needs (Alexander, 1996). This definition is in tandem with total quality management's definition of service to the client from the perspective of the customers, employees, suppliers, investors or a community.

A recent attempt by Tay and Ooi (2001) (In Brochener, 2003), to harmonize eight current and influential definitions of FM led to the identification of Facilities Management as the integrated management of the workplace to enhance the performance of the organization. According to the study, Facilities Managers are responsible for ensuring cost efficient management of the building and related facilities, and creating an environment that supports the activities of the building users, and their experience and knowledge would provide vital background to building related decisions. Maas and Pleunis (2001) (In Hassanien and Losekoot, 2002) sees FM as "the responsibility for co-ordinating efforts to ensure that buildings, technology, furniture and organizational trends are responded to, over time". Furthermore, Barett (2000) defines FM as "an integrated approach to operating, maintaining, improving, and adopting the buildings and infrastructure of an organization in order to create an environment that strongly supports the primary objectives of that organization". However, neither definition refers to the process or activities, which are associated with facilities management. Also, they do not stress the positive contributions which well-managed facilities could make to an organization. It may therefore be deduced from the definitions that as many practitioners of FM as are available so are the scope and concept of FM. The varied definitions of FM implies that it is an evolving field whose nature is still somewhat fluid and thus portraying it as an all embracing and evocative tool that should normally be an aspect of the organization organogram of any going concern. Apart from this, it serves as a strategic tool deployable to reversing the downward trend of any ailing organization.

Thus, facilities management is an instrument of strategic change which in hotel circles is called re-engineering. Hammer and Campy (1993) (In Nebel et al., 2002) defined re-engineering as "the fundamental rethinking and radical redesign of business processes to achieve dramatic improvements in critical, contemporary measures of performance, such as cost, quality, service and speed". How committed is the organization to this re-engineering? The four fundamental steps that are instrumental to re-engineering hotel operations according to Furey (1993) (In Nebel et al., 2002) involve identifying process objectives from customers' perspective; understanding existing process; benchmarking; re-engineering the process and implementing the new process. There must be radical departure from the past and aggressive commitment to improvement, new ways of doing things and innovation. Thus, there must be differentiation and focus, adoption of on-going style, provision of a role model, wooing of the customers and re-assurance as far as support services are concerned in hotel business. Table 1 shows the features of a re-engineered hotel and the benefits of re-engineering.

Okoroh, Jones and Ilozor (2003) dwelt on adding value to constructed facilities with emphasis on the hospitality industry with the aim of examining the impact of service contact on the perceived quality and nature of the accommodation package using survey questionnaire for data gathering and the personal construct theory for the 
analysis of the generated data. In their own opinion, a very large proportion of the product relates to the management of the core activities that center on built facilities. There is a need for life cycle planning of these facilities, their capacity, use and proactive maintenance policy, as well as the resources needed to cope with changing demands. Factors such as life cycle costing, productivity, performance values, and legislative change drive facilities management. In conclusion they opined that given the nature, characteristics, variety of components, and related economic aspects of hotels, it seems that there are benefits to be derived from the application of FM in hotel businesses. For instance, owners/owner managers in the sector and the location studied, who are more proactive in the management of their constructed facilities, achieved higher occupancy rates, profitability and repeat business. Proactive management becomes essential when it is realized that service products essentially propel hotel products. Thus, hotel accommodation package to be effective and satisfy customer needs must be accompanied by intangible services such as security and feeling of well-being.

From the definitions and for the purpose of this study, FM is construed to be a strategic management tool that seeks to exploit the dichotomy between workplace, people and the work of the organization by turning potentiality to reality through proactive management.

\section{Research method}

An exploratory cross-sectional survey approach devoid of control and involving one-time observation of independent and non-manipulated variables was adopted in the study, which covers the South-Western geo-political zone of Nigeria. The zone consists of six States namely Lagos, Ekiti, Ogun, Oyo, Osun and Ondo with their capital city as Ikeja, Ado-Ekiti, Abeokuta, Ibadan, Oshogbo and Akure respectively as shown in Fig.1. The six States are contiguous and possess similar attributes that allowed easy comparability, improved homogeneity of the population and reduced the sampling errors.

In taking samples of the hotel, consideration was given to those that meet the National Classification and Grading of Hotels standard in consonance with the policy of Nigeria Tourism Development Corporation (2001). There are one hundred and eighty-two hotels out of which Ekiti accounted for 35 (19\%), Lagos 42 (23\%), Ogun $39(21 \%)$, Ondo $22(12 \%)$, Osun $18(10 \%)$ and Oyo $26(14 \%)$ respectively. Out of the total of one hundred and eighty-two hotels, a total of eighty hotels $(44 \%)$ were located within the State capitals. The breakdown of the hotels in the capitals indicated that Ado-Ekiti had $13(16 \%)$, Ikeja 29 (36\%), Abeokuta $11(14 \%)$, Akure $8(10 \%)$, Oshogbo $3(4 \%)$ and Ibadan $16(20 \%)$. The State capitals were thus selected as a result of great concentration of the hotels and the capitals are seat of governance and tourist destinations.

In determining the acceptable sample size, Kothari's (1978) formula was adopted with confidence level set at $95 \%$ and a 0.02 probable error. By this method, the appropriate sample size of 57 was obtained and split based on the number of hotels within each State. Data collection instrument consisted of self-administered questionnaires which were administered on the hotel management and customers complemented with in-depth personal interview and physical survey of the constructed facilities. The questionnaire administered on the hotel management was divisible into three major sections namely the general information about the hotel; the general characteristics of the General Manager and then facilities management variables, while those administered on the customers was composed of the general characteristics of the respondents and the perception of support services' management by the customers. The number of questionnaires administered to customers was based on pilot survey carried out on customers' turnover for the past five years from which average monthly and daily averages were determined. Out of fifty-seven questionnaires administered on hotel management, twenty-eight $(49 \%)$ were returned. In respect of customers, a total of six hundred and seventy-one questionnaires were distributed out of which three hundred and sixty (54\%) were retrieved as shown in Table 2.

As Kerlinger (1973) puts it, content validity is the representativeness or sampling adequacy of the content of a measuring instrument. Kerlinger further explained that "other competent judges should judge the content of the items". In order to achieve this for the study, experts' opinion in environmental sciences, behavioral sciences, psychology, marketing and the hotel industry were sought and they assessed the relevance and appropriateness of the statements in the questionnaires.

Data analysis was carried out with the aid of descriptive statistics and balanced scorecard. The Balanced Scorecard (BSC) attempts to translate the sometimes vague, pious hopes of a company's vision, mission statement into the practicalities of managing the business better at every level. A balanced scorecard approach is to take a holistic view of an organization and co-ordinate metric driven incentives (MDIs) so that efficiencies are experienced by all departments and in a joined- up fashion. Typical factors considered in a balanced scorecard are finance, internal business processes, learning and growth and customer. Once an organization has analyzed the quantifiable results, they should be ready to utilize the BSC approach to improve the areas where they are 
deficient. The metrics set-up also must be specific, measurable, achievable, realistic and timely. It is said that you cannot improve on what you cannot measure. Metrics must be aligned with the company's strategic plan (Kaplan and Norton, 1996).

Borrowing from the ideas of BSC the metric driven incentives are taken to be a degree of adoption of facilities management, level of business development, degree of use of information and communication technology and level of support services outsourcing as shown in Figure 2. This is possible by relying on the RICS FM skills panel postulation that FM consists of three but inter related areas: the management of support services, the management of property and the management of information technology. For this work, property is taken to mean facilities while business development is expected to be a variable common to all strategic management driven organizations and the four variables are measurable.

Ghiselli and Brown (1978) in turn emphasized that 'test validation studies must be carried out on a group of testers, representative of those on whom the test eventually will be used'. This criterion was followed in this study. For the face and content validity, a superficial examination of the content of the instrument was carried out in order to ensure that questions that needed to be raised were asked. The reliability of the instruments was tested using the split-half method. A corrected coefficient of 0.76 was obtained and this was considered high enough for this type of study in line with Glass and Stanley (1970).

It is recognized that, in some ways, any research work would have limitations. For this research, there is little published work relating to hotels in Nigeria, and what is available mainly focused on the privatization of government hotels. Also, as highlighted by Asika (1991), there are various barriers to the collection and exchange of information, compounded by the location and the remoteness of some hotels and fears about commercial confidentiality. All these had been guided against in the sample frame and sample size selection. However, geographical limitation as introduced above and the adoption of Tourism Board list may inevitably introduce limited bias into the survey, which could limit the application of the results to geographically dissimilar areas. It is anticipated that the results could at least form the framework for future research of other far away locations in the country.

\section{Result and discussion}

\subsection{Degree of use of facilities management as property management style}

Effectiveness of a hotel is greatly influenced by the facilities it has, accommodation on offer, customer disposition and their property asset management style. Property asset management style in this regard could be maintenance management, property management, facilities benchmarking and facilities management. Facilities benchmarking is a component of facilities management and often regarded as a threshold of FM. This section tries to establish the operating property asset management style among the hotels from organization perspective.

Table 3 shows the prevailing management style put in place for running the hotels' properties. Fifty seven percent adopt maintenance management, twenty five percent favor facilities bench marking, and eleven percent operates facilities management while seven percent favor property management. This shows that maintenance management still predominates in the industry while facilities management is just filtering into the industry with interim emphasis on facilities bench marking while property management is lagging behind or not favored in the industry. Maintenance management topping the list could be attributed to conservatism, sticking to the way it has always been done or the belief in its efficacy. Facilities bench marking coming second could be attributed to the desire to try new ways perhaps avoiding losing out completely while facilities management status could be due to hotel chain scenario where affiliated hotel adopts what operates down the line. The researcher is of the opinion that non-acceptance of property management is due largely to the fact that hoteliers prefer to run their hotels themselves or get closely linked with the hotel and that building hotels for letting is an un-popular venture. However, further analysis shows the hotels and their property assets' management style. Maintenance management practice as shown in Table 3 cuts across all the categories of hotels studied. Facilities management practice is limited to 5-Star hotels while facilities bench marking is found among 4 to 5-Star hotels. Thus, 3 hotels $(11 \%)$ have full blown facilities management system, 7 hotels $(25 \%)$ practice facilities benchmarking, 2 hotels (7\%) practice property management and the remaining hotels maintenance management (57\%).

If facilities benchmarking is merged with facilities management overall, $36 \%$ is achieved. This finding is not strange as it accords with Wai (2004) who averred that facilities management is a new idea in hotel management and renovation. However, it runs contrary to the averment of Alexander (1996) that only by being tuned to business objectives and married to a strategic plan can organizations encourage innovation and enterprise. This is a strategic role for organizations - to develop policy, contribute to strategic planning, negotiate service levels 
and arrange for the delivery of quality facilities. It is thus important for hotels to exploit new ways of doing things especially if such would add value to the organization's process and improve its effectiveness.

\subsection{Level of business development in the hotels}

The analysis of business development was achieved by evaluating the number of hotels that have business development department, degree of commitment to strategic management or what could be called trouble shooting activities, research interest, commitment to feedback evaluation and customers' welfare. The synergy arising from all these definitely boosts commitment to facilities management and can be summed up using balanced score card principle. All these were examined from hotel managements' perspectives. Table 4 is a summary of the responses. From Table 4, twenty hotels possess business development department as against eight that do not have representing $71 \%$ and $29 \%$ respectively. This incidence of business development unit could probably be due to the desire to explore other business areas or just as a unit serving other business areas in addition to the hotel business. For sensitivity to hotel property performance, sixteen hotels displayed this trait while twelve do not representing $57 \%$ and $43 \%$ respectively. In terms of strategic evaluation of services, twenty-four hotels possess this trait while four hotels do not representing $86 \%$ and $14 \%$ respectively.

For the concern for customers' welfare twelve hotels bothered so much about this as against sixteen hotels which care less representing $43 \%$ and $57 \%$ respectively. In areas of market research 16 hotels do bother to carry this out representing $57 \%$ while in areas of feedback assessment only one hotel do bother representing $4 \%$. This poor concern for feedback might be due to ineptitude or lack of interest. The average of these percentages gave $46 \%$ for ownership and strategic evaluation. Thus, business development consciousness could be regarded as below average. The reasons for this result could be that competition in this business is not fierce and that hotel businesses are profitable without much stress.

\subsection{Level of compliance with information and communication technology in the hotels}

This is assessed from customers' perspective to avoid bias that may be displayed by the organizations since this is the era of information and telecommunication technology (ICT). The major issues considered include computer ownership, web hosting, e-payment, e-booking and internet access. Table 6 below is the summary of frequency distribution for the responses. From Table 5, a large number of the hotels have computers $(58 \%)$ and owned website (53\%) but in terms of use for e - payment, e - booking and internet access, it is at low ebb (32\%). Since use or deployment contributes significantly to operational efficiency than ownership, it can be concluded that information and communication technology (ICT) is just at a threshold of application.

The importance of ICT had been emphasized by many writers. Joudah (1996) was of the opinion that the information concerned with FM processes and functions is considerable. Handling it is complex and the way data are structured, collected, collated, distributed, presented and updated determines whether these data are informative and suitable for the process of making various decisions. Other writers such as Hamer (1988), Hamermesh (1990), Spedding (1999) and Grimshaw (2003) aligned with this disposition. Siguaw and Enz (2002) affirmed that the successful companies of the next decade will be the ones that use digital tools to reinvent the way they work. These companies will make decisions quickly, act efficiently, and directly touch their customers in positive ways. The industry practitioners interviewed were of the opinion that the low level of use of ICT is not unconnected with the low use of ICT in Nigeria and that as people get more used to ICT, the industry will pick up accordingly.

\subsection{Support services outsourcing in studied hotels}

In terms of procurement of support services from organization perspective the GMs were asked to identify the procurement method best suited for each support service. Current procurement method from facilities management perspectives is that support services should be majorly outsourced to ease the burdens of procurement on the management [Owen (1993), Spedding (1999)] and so a sound procurement must be the one that is anchored to outsourcing. Table 6 shows the frequency distribution for support services procurement.

The prevalence of in-house procurement as against outsourcing is not in consonance with facilities management practice as propounded by Owen (1993), Bernard Williams Associates (1996) and Spedding (1999).

In summary, it could be seen that the use of FM as strategic management tool is $36 \%$, level of business development is $46 \%$, use of ICT is $39 \%$ and support services outsourcing is $46 \%$, all below average. Using balanced score card, it could be deduced that all the four are balanced but in a negative sense. This may imply that strategic management practices in south-western Nigeria hotels is at low ebb and perhaps affecting growth and development of the hotels. 


\section{Conclusion and recommendation}

It is noteworthy from the study that the four variables; use of Facilities Management (36\%), Level of Business Development (46\%), Level of Compliant with Information and Communication Technology (39\%) and Support Services Outsourcing (46\%) are all at low ebb and using balanced score card all could be regarded as balanced but in a negative sense suggesting low level of strategic management practices in running the hotels.

This study also buttressed the assertion that application of facilities management principles in the management of the hotels within the study area is at low ebb suggesting un-popularity among hotel stakeholders. Accelerated education of the populace through the print media, radio and television programmes, training and re-training of people in this field is considered as the way out. This can be achieved by government through Ministries of Education and National University Commission (NUC) encouraging and supporting training and research in this field. Furthermore, International Facilities Management Association, Nigeria Chapter (IFMANC) should pursue vigorously the enabling law establishing Nigerian Facilities Management Association (NFMAS) which once established should concentrate more on research, training, marketing and promotion of the profession. In addition, NFMAS should establish a standard of practice, code of conduct, standard of training and encouraging continuing professional development through seminars, workshop, in-service training and public lectures. The hotel managements are further encouraged not to be lukewarm in adapting to new ways of doing things and in particular be responsive to the use of strategic management principles.

\section{References}

Alexander, K (2003). A Strategy for Facilities Management. Facilities, 21(11/12), 269 - 2741. http://dx.doi.org/10.1108/02632770310500338

Alexander, K. (1996). Facilities Management: Overview. In Alexander, K [Ed.]. Facilities Management London: Theory and Practice (pp. 1-12). London E \& FN Spon.

Amaratunga, D. (2000). Building Performance Evaluation in Higher Education Properties: A Facilities Management Approach. RICS Foundation, 3 (14), 1-21.

Asika, N. (1991). Research Methodology in the Behavioral Sciences (1 ${ }^{\text {st }}$ Ed.). Lagos: Longman Nigeria Plc.

Barrett, P. (2000). Achieving Strategic Facilities Management through Strong Relationships. Facilities 18(10//11/12), $421-426$.

Bernard Williams Associates. (1996). Facilities Economics. Building Economics Bureaus Ltd., Kent. Pp 1-3.

Bevan, O.A. (1991). Marketing and Property People ( $1^{\text {st }}$ Edition). London: Macmillan Press Ltd.

Bode-Thomas, A. I. (2003). Nigerian Hotels Have improved. The Guardian, September 12, 2003, 20(9,061), P.51.

British Institute of Facilities Management. (1995). The Learning Curve. Chartered Surveyor Monthly. Supplement June 1995, Pp II - IV.

Brochener, J. (2003). Integrated Development of Facilities Design and Services. Journal of Performance of Constructed Facilities, February 19-23. http://dx.doi.org/10.1061/(ASCE)0887-3828(2003)17:1(19)

Collins, E.G.C., and Devanna, M.A. (1990). Portable MBA ( $1^{\text {st }}$ Ed.). London: Safari Books (Export) Limited.

Cowan, A. (2001). Information is Key to Facilities Management Planning. Chartered Surveyor Monthly, April $2001,32-33$.

Dada, A. (2005). Global Fleet Acquires FG's VI Guesthouses, Plans Five-star Hotel. The Punch, November 28, $17(19,485), 37$.

Eddystone, C., Nebel, III., Rutherford, D.G., and Schaffer, J.D. (2002). Reengineering the Hotel Organization. In Rutherford, D. G [Ed.], Hotel Management and Operations ( $3^{\text {rd }}$ Ed.). (pp. 55-63). New York: John Wiley \& Sons, Inc.

Edum-Fotwe, F.T., Egbu C., and Gibb, A.G.F. (2003). Designing Facilities Management Needs into Infrastructure Projects: Case from a Major Hospital. Journal of Performance of Constructed Facilities, February, 44-50.

Ghiselli, E.E., and Brown, C.W. (1978). Personnel and Industrial Psychology (1 ${ }^{\text {st }}$ ed.). New York: McGraw-Hill.

Glass, G.V., and Stanley, J.C. (1970). Statistical Methods in Education and Psychology. (2 ${ }^{\text {nd }}$ Ed.). New Jersey: Prentice-Hall. 
Green, A., and Price, I. (2000). Whither FM/ A Delphi Study of the Profession and the Industry. Facilities, 18 (7/8), 281 - 293. http://dx.doi.org/10.1108/02632770010340672

Grimshaw, R.W. (2003). FM: The Professional Interface. Facilities, 21(3/4), 50 - 57. http://dx.doi.org/10.1108/02632770310469352

Hamer, J.M. (1988). Facility Management System (1 $1^{\text {st }}$ Ed.). New York: Van Nostrand Reinhold Inc.

Hamermesh, R. G. (1990). Strategic Management. In Collins, E.G.C and Devanna, M.A [Eds]. Portable MBA. London: Safari Books (Export) Limited.

Hassanien, A., and Losekoot, E. (2002). The Application of Facilities Management Expertise to the Hotel Renovation Process. Facilities, 20(7/8), 230 - 238. http://dx.doi.org/10.1108/02632770210435143

Joudah, Ameen. (1996). Information management. In Alexander, K [Ed.]. Facilities Management London: Theory and Practice (pp. 121-132). London E \& FN Spon.

Kaplan, R.S., and Norton, D.P. (1996). Using balanced scorecard as a strategic management system. Harvard Business Review, January - February, $75-85$.

Kerlinger, F.N. (1973). Foundations of Behavioural Research. London: Holt, Rinehart and Winston.

Kothari, C.R. (1978). Quantitative Techniques ( $3^{\text {rd }}$ Ed.). New Delhi: Vikas Publishing House PVT Ltd.

Nebel, E.C., Rutherford, D.G., and Schaffer, J. D. (2002). Reengineering the Hotel Organization. In Rutherford, D. G [Ed.]. Hotel Management and Operations ( ${ }^{\text {rd }}$ Ed.). (pp. 55-63). New York: John Wiley \& Sons, Inc.

Nigerian Tourism Development Corporation (NTDC). (2001). Standard for National Classification and Grading of Hotels and Other Serviced Accommodations in Nigeria ( $1^{\text {st }}$ Ed.). Abuja: Nigerian Tourism Development Corporation.

Nutt, B. (1999). The Future of Facilities Management: Context, Research and Theory. Facilities, 17(1/2), 11-17. http://dx.doi.org/10.1108/02632779910248406

Okoroh, M.I., Jones, C.M., and Ilozor, B.D. (2003). Adding Value to Constructed Facilities: Facilities Management Hospitality Case Study. Journal of Performance of Constructed Facilities, February, 24-33. http://dx.doi.org/10.1061/(ASCE)0887-3828(2003)17:1(24)

Owen, D. (1993). Facilities Management: What Chartered Surveyors Need to Know. Chartered Surveyor Monthly, Vol. II, Issue 9 June.

Owen, D. (1995). FM is not Just a Radio Station. Chartered Surveyor Monthly, Supplement, June pp II - IV.

Rufai, A. (2003). The Imperatives For Re - inventing NSITF. The Guardian, July $10^{\text {th }}, 20(8), 8$.

Rutherford, D.G. (2002). As I See It: Organization Structure. In Rutherford, D. G [Ed.]. Hotel Management and Operations ( ${ }^{\text {rd }}$ Ed.). (pp. 55-63). New York: John Wiley \& Sons, Inc.

Siguaw, J.A., and Enz, C. A. (2002). Best Practices in Information Technology. In Rutherford D.G [Ed.]. Hotel Management and Operations ( $3^{\text {rd }}$ Ed.). (pp. 428-444). New York: John Wiley \& Sons, Inc.

Spedding, A. (1999). Facilities Management and the Business Organization. The Quantity Surveyor, Vol.29, Oct/Dec. Pp. 2-8.

Tay, L., and Ooi, J.T.L. (2001). Facilities Management: A 'Jack of All Trades'? Facilities, 19(10), 357-362. http://dx.doi.org/10.1108/EUM0000000005534

Telfer, A. (2005). Hotel Supply Chain: A Strategic Approach. European Hotel Managers Association. [Online] Available: http://www.hilton.com

The Royal Institution of Chartered Surveyors. (1993). Facilities Management: An Overview of the UK Industry. Chartered Surveyor Monthly September, 3(1), 13-15.

The Royal Institution of Chartered Surveyors. (1993). The Learning Curve. Chartered Surveyor Monthly, September, 3(1), IX -XI.

Torkildsen, G. (1992). Leisure Recreation Management ( $3^{\text {rd }}$ Ed.). London: E \& FN Spon.

Udo, G.O. (1998). The Relationship Between Facilities Management and Property Management. $28^{\text {th }}$ Annual Conference on "Facilities Management in Nigeria - The Estate Surveyor and Valuer's Perspective". Paper delivered at Royal Tropicana Hotel, Kano $24^{\text {th }}-29^{\text {th }}$ March 1998. 
Wai. K.C. (2004). The Application of Facilities Management to Hotel Renovations in Hong Kong. [Online] Available: www.hub.hku.hk/handle/123456789/48845

Table 1. Features of reengineered hotel and benefits of reengineering

\begin{tabular}{|c|c|}
\hline Features of Re-engineered Hotel & Benefits of Re-engineering \\
\hline $\begin{array}{l}\text { Fundamental work units change from } \\
\text { functional, task-driven departments to process teams. } \\
\text { - } \quad \text { Organizational structures change from } \\
\text { hierarchical (pyramids) to flat. } \\
\text { - } \quad \text { Jobs within process teams become } \\
\text { multidimensional. } \\
\text { - } \quad \text { Workers become empowered to make } \\
\text { decisions } \\
\text { - } \quad \text { Job preparation shifts from training to } \\
\text { education. } \\
\text { - } \quad \text { Performance is measured by results that are } \\
\text { customer-based rather than task-oriented } \\
\text { - } \quad \text { Executives change from checkers and } \\
\text { arbitrators to leaders and facilitators } \\
\text { - } \\
\text { on past performance. } \\
\text { - } \\
\text { protective of their turf and more productive. }\end{array}$ & $\begin{array}{l}\text { Employees are organized into teams where } \\
\text { the work focuses exclusively on customer-driven } \\
\text { outcomes } \\
\text { - } \quad \text { Team performance is measured by } \\
\text { customer-based criteria. } \\
\text { - Teams are able to coordinate their activities } \\
\text { without the need for outside intervention } \\
\text { - } \quad \text { Decisions are made where the work is } \\
\text { being performed } \\
\text { - } \quad \text { Executives become facilitators and leaders } \\
\text { rather than checkers and arbitrators. } \\
\text { - } \quad \text { Dramatic improvements in output measures } \\
\text { are possible, whereas traditional approaches after, at } \\
\text { best, incremental gains. }\end{array}$ \\
\hline
\end{tabular}

Source: Nebel, Rutherford and Schaffer (2002) 
Table 2. Summary of distributed customers' questionnaires

\begin{tabular}{|c|c|c|c|}
\hline S/No & Hotels & Location & $\begin{array}{c}\text { No of } \\
\text { Questionnaires }\end{array}$ \\
\hline 1 & Mainland & Lagos & 49 \\
\hline 2 & Federal Palace & Lagos & 50 \\
\hline 3 & $\begin{array}{l}\text { Lagos Sheraton and } \\
\text { Towers }\end{array}$ & Lagos & 51 \\
\hline 4 & Niger Palace & Lagos & 9 \\
\hline 5 & Hotel Plaza & Lagos & 19 \\
\hline 6 & Le'Eko Meridien & Lagos & 43 \\
\hline 7 & Excellence & Lagos & 20 \\
\hline 8 & Kilo & Lagos & 21 \\
\hline 9 & Oasis & Lagos & 13 \\
\hline 10 & Hotel Newcastle & Lagos & 21 \\
\hline 11 & Bluenet & Lagos & 8 \\
\hline 12 & Lagos Airport Hotel & Lagos & 32 \\
\hline 13 & West End & Ado-Ekiti & 19 \\
\hline 14 & Olujoda & Ado-Ekiti & 16 \\
\hline 15 & Owena & Akure & 20 \\
\hline 16 & Lafia & Ibadan & 36 \\
\hline 17 & Premier & Ibadan & 64 \\
\hline 18 & Greenspring & Ibadan & 11 \\
\hline 19 & K.S Motel & Ibadan & 17 \\
\hline 20 & D'erovan Hotel & Ibadan & 12 \\
\hline 21 & Kankanfo Inn & Ibadan & 17 \\
\hline 22 & MicCom Golf & Oshogbo & 13 \\
\hline 23 & Heritage & Oshogbo & 18 \\
\hline 24 & Leisure Spring & Oshogbo & 18 \\
\hline 25 & Universal & Abeokuta & 7 \\
\hline 26 & Adesbar & Abeokuta & 10 \\
\hline 27 & Dusmar & Abeokuta & 22 \\
\hline \multirow[t]{2}{*}{28} & Gateway & Abeokuta & 35 \\
\hline & & Total & 671 \\
\hline
\end{tabular}


Table 3. Hotels and their property asset management style

\begin{tabular}{|c|c|c|c|c|}
\hline $\mathrm{S} / \mathrm{No}$ & Maintenance & Property & Facilities & Facilities \\
\hline & Management & Management & Management & Bench Marking \\
\hline 1 & West End Hotel & Hotel Plaza & Federal Palace Hotel & Mainland Hotel \\
\hline 2 & Olujoda Hotel & Oasis Hotel & Lagos Sheraton Hotel & Gateway Hotel \\
\hline 3 & Owena Motel & & L'Eko Meridien Hotel & Excellence Hotel \\
\hline 4 & Niger Palace Hotel & & & Lagos Airport Hotel \\
\hline 5 & Kilo Hotel & & & Premier Hotel \\
\hline 6 & Bluenet Hotel & & & MicCom Golf Hotel \\
\hline 7 & Hotel Newcastle & & & Kankanfo Hotel \\
\hline 8 & Lafia Hotel & & & \\
\hline 9 & Heritage Hotel & & & \\
\hline 10 & Universal Hotel & & & \\
\hline 11 & Greenspring Hotel & & & \\
\hline 12 & D'Erovan Hotel & & & \\
\hline 13 & Adesba Hotel & & & \\
\hline 14 & K.S Motel & & & \\
\hline 15 & dusmar Hotel & & & \\
\hline 16 & \multicolumn{2}{|l|}{ Leisure Spring Hotel } & & \\
\hline Total & 16 & 2 & 3 & 7 \\
\hline \multirow[t]{3}{*}{$\%$} & 57 & 7 & 11 & 25 \\
\hline & A & B & $\mathrm{C}$ & $\mathrm{D}$ \\
\hline & & & & $C+D=36 \%$ \\
\hline
\end{tabular}

Table 4. Frequency distribution for business development parameters

\begin{tabular}{|l|l|c|c|c|}
\hline S/No & Parameters & Yes & No & $\%($ Yes $)$ \\
\hline 1 & $\begin{array}{l}\text { Business } \\
\text { Development Unit } \\
\text { [Operating] }\end{array}$ & 8 & 20 & 29 \\
\hline & $\begin{array}{l}\text { Proactiveness } \\
\text { Measure }\end{array}$ & & & \\
\hline 2 & $\begin{array}{l}\text { Care for } \\
\text { Performance of } \\
\text { Hotel Properties }\end{array}$ & 16 & 12 & 57 \\
\hline 3 & $\begin{array}{l}\text { Strategic Evaluation } \\
\text { of Services }\end{array}$ & 24 & 4 & 86 \\
\hline 4 & $\begin{array}{l}\text { Concern for } \\
\text { Customers' Welfare }\end{array}$ & 12 & 16 & 43 \\
\hline 5 & $\begin{array}{l}\text { Feedback } \\
\text { Assessment }\end{array}$ & 1 & 27 & 4 \\
\hline 6 & Market Research & 16 & 12 & 276 \\
\hline & Sum & & & 46 \\
\hline & Average & & & \\
\hline
\end{tabular}


Table 5. ICT variables' analysis

\begin{tabular}{|l|c|c|c|}
\hline ICT Variables & No & Yes & $\%$ of Yes to \\
(Frequency) & (Frequency) & Total \\
\hline Computerization & 150 & 210 & 58 \\
\hline Web Ownership & 171 & 189 & 53 \\
\hline E-payment & 263 & 97 & 27 \\
\hline E- booking & 287 & 73 & 20 \\
\hline Internet access & 259 & 101 & 39 \\
\hline Average & & & 39 \\
\hline
\end{tabular}

Table 6. Support services procurement frequency analysis

\begin{tabular}{|l|c|c|c|c|}
\hline Support & In-House & In-House & External & External \\
\hline Services & Procurement & Procurement & Outsourcing & Outsourcing \\
\hline & Organizations & $\begin{array}{c}\text { Facilities } \\
\text { Managers }\end{array}$ & Organization & Facilities Managers \\
\hline Mail services & 6 & 8 & 22 & 20 \\
\hline Fleet Cars & 27 & 27 & 1 & 1 \\
\hline Catering & 25 & 28 & 3 & 0 \\
\hline Reception & 20 & 28 & 8 & 0 \\
\hline House Keeping & 18 & 28 & 9 & 0 \\
\hline Office administration & 16 & 20 & 12 & 8 \\
\hline Refuse Disposal & 3 & 8 & 25 & 20 \\
\hline Reprographics & 4 & 16 & 24 & 0 \\
\hline Security & 26 & 28 & 2 & 24 \\
\hline Stationery & 28 & 4 & 0 & 21 \\
\hline Travel arrangement & 28 & 7 & 0 & 2 \\
\hline Vending & 28 & 15 & 0 & 3 \\
\hline Furniture & 2 & 26 & 26 & 19 \\
\hline Purchasing & 3 & 25 & 25 & 16 \\
\hline Car Park & 22 & 9 & 6 & 0 \\
\hline Management & 28 & 12 & 0 & \\
\hline Horticulture & 28 & 11 & & \\
\hline Porterage & & & & \\
\hline
\end{tabular}




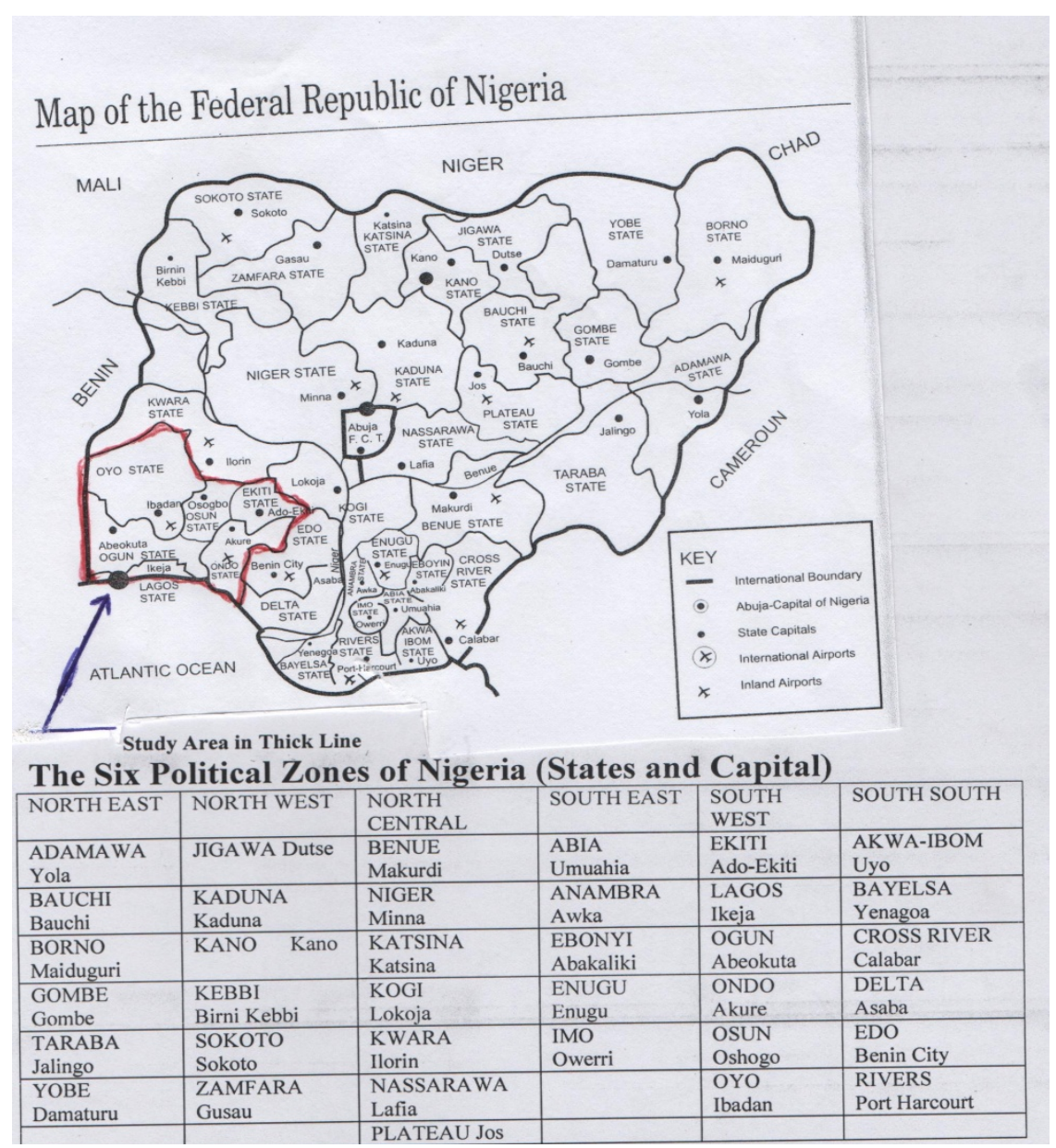

Figure 1. Map of Nigeria showing the study area in thick line and the six Geo-Political Zones

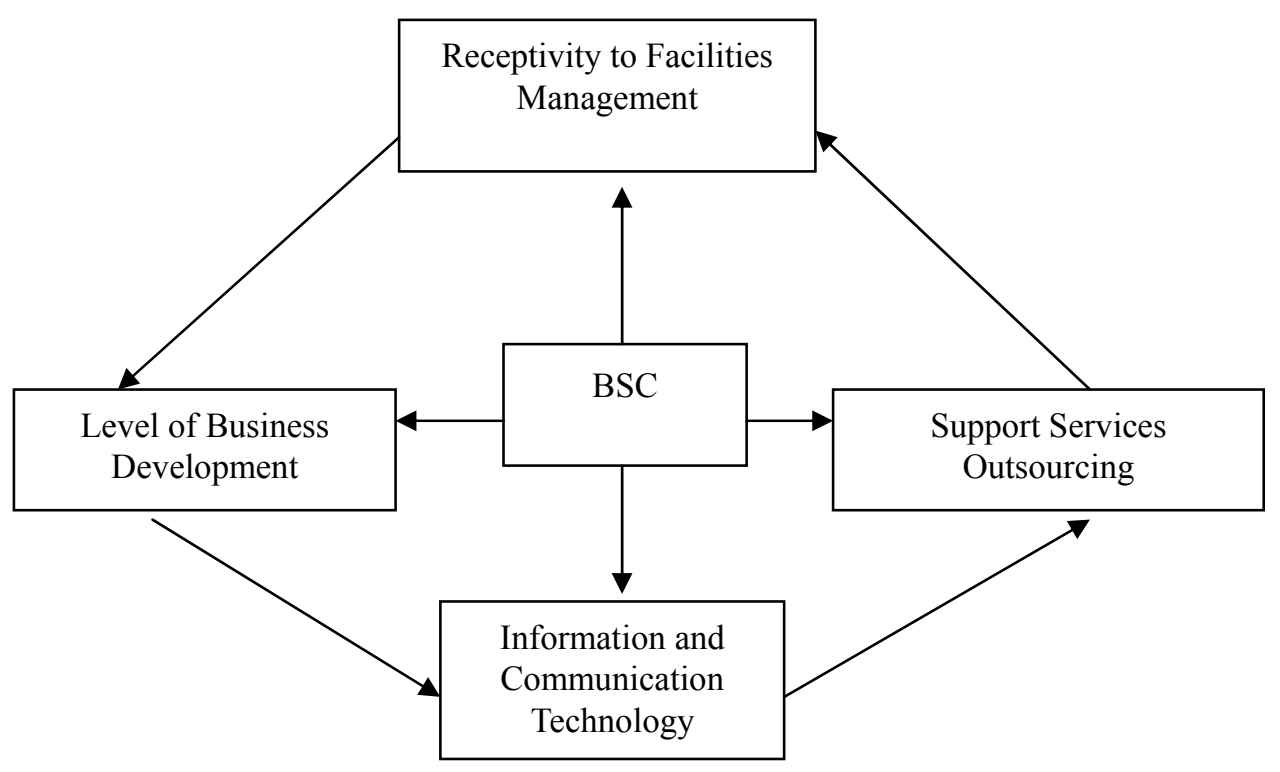

Figure 2. The BSC: A system for strategic implementation

Source: Amaratunga (2000) 